\title{
THE STATUS OF SOCIAL WORK AS PERCEIVED BY KEY HUMAN SERVICE PROFESSIONALS
}

\section{Tanusha Raniga, Madhu Kasiram}

\section{INTRODUCTION AND RATIONALE FOR THE STUDY}

First-hand experience in various practice settings points to large-scale misunderstanding, ignorance and undervaluing of social work. In fact, it may be argued that the social worker is often confused, lacks confidence and has a weak voice when compared to other professionals. Barter (cited in Shera, 2003:203) adds that the profession is indeed actively marginalised and is losing ground to nurses, health workers and occupational therapists. Dane and Simone (cited in Dittrich, 1994:19) also mention this marginality and token status that is generally attributed to social workers in secondary settings such as hospitals, schools, legal aid offices, nursing homes, business and industry. Their explanation for this perception is that, where social workers are few in number but their visibility high, this may lead to their decisions being constantly scrutinised, thereby undervaluing and undermining their worth. To add to this complexity these writers introduce the dimension of gender into the undervaluing of the profession, stating that social work may be "devalued as women's work in such settings that are predominantly male in inspiration" (Dittrich, 1994:20).

Moreover, in South Africa since 1994 social work as a core human service profession has been experiencing its own parallel process of transformation and undergoing a major paradigm shift (Raniga, 2006). This has been a major undertaking that involves the critical examination of current social work roles, programmes and services within a changing socio-political context (Holscher, Kasiram \& Sathiparsad, 2009). However, the general public, professionals and nonprofessionals seem not to appreciate the shift and often continue to hold obsolete perceptions of the profession. Such devaluing of social work is disconcerting, given the urgent need to address the shortage of social workers in the country (Kasiram, 2009). Child Welfare South Africa (2004) documents that the majority of social workers employed by its member organisations leave their jobs before completing five years of service, which has resulted in instability and inexperience within the service context. Naidoo and Kasiram (2003) revealed that safety and security, service conditions, poor salaries, staff turnover and curriculum changes were the major reasons cited by social workers in emigrating to developed countries, leaving a vacuum in the workforce and straining existing social workers' resources. How then can a stretched workforce continue to offer a quality service?

To this end the researchers explored the assumptions and parameters of social work in order to contribute to the protection and promotion of its professional standing. Together with understanding how other human service professionals perceive social work, the study recommends how training, teamwork and the general image of social work may be enhanced to allow improved access to, and delivery of, services in South Africa.

\section{AIM AND OBJECTIVES OF THE STUDY}

The main aim of the study was to identify perceptions of social work from other human service professionals. This was achieved through the pursuit of the following objectives:

- Identifying whether key human service professionals see a need for social work services; 
- Investigating what knowledge these professionals have regarding the various roles and responsibilities of social workers;

- Understanding challenges experienced by professionals in networking optimally with social workers;

- Exploring professionals' perceptions on strengthening relationships with social workers.

\section{THEORETICAL FRAMEWORK}

Anti-oppressive theory (AOP), traditionally developed from the social justice and radical structuralist school of thought, forms the theoretical backdrop to the study. Scholars such as Mullaly (1997), Ife (2001), Moreau and Leonard (cited in Allan, 2003), Dominelli (2004), Sewpaul $(2005,2006)$ and more recently Baines (2007) indicate that anti-oppressive theory is critical of social problems that are perceived as pathological and located at the level of the individual, with little or no emphasis on challenging power relations, structures, or the cultural or economic forces of oppression.

Additionally, Baines (2007) and Ife (2001) argue that the crisis experienced by social work involves not only a struggle over power and resources, but affirming professional identities, indeed referring to its very legitimacy. Shera (2003:102) clarifies that AOP is concerned with eradicating social injustice and there is no doubt that the underrating of social work by other professions is a form of injustice directed at the profession. Dominelli (2002b:08) supports this argument in stating that "oppression involves relations of domination that divide people into dominant or superior groups and subordinate or inferior", making a case for the use of AOP theory in understanding how social work has sunk to such an "inferior" status.

\section{RESEARCH METHODOLOGY}

Both quantitative and qualitative designs were employed as the strategic framework for execution of the research aims (Terre Blanche \& Durrheim, 1999). Self-administered questionnaires and semi-structured interviews were regarded as best serving the purposes of the study. Triangulation was thus achieved in using two research approaches, research instruments and samples. The advantage of using multiple data collection sources (educators, doctors, nurses, VCT counsellors, psychologists, police personnel) and strategies (questionnaires and indepth interviews) enhanced the reliability and validity of the data.

The quantitative component was used to elicit facts and statistics that were considered useful in determining the number of people within the sample who had certain perceptions about social work. The fieldwork for this part of the study was completed by four social work students in their final year of study.

The qualitative component was executed through in-depth interviews to glean rich, descriptive data on what, how and why certain perceptions of social work existed, explaining and illuminating findings from the quantitative component. Data for this component of the study were collected by two final-year social work students.

In both the qualitative and quantitative components non-probability sampling (Babbie \& Mouton, 2001), specifically availability sampling, was used with both sample groups, since only persons willing to participate could be accessed. Thus researchers personally approached potential participants in their fieldwork environment to enlist their cooperation.

The final sample frame consisted of 82 participants, 60 from four professional groups (teachers, policemen, nurses and doctors) for the quantitative component and 22 health professionals 
(doctors, nurses, psychologists and VCT counsellors) from two hospitals for the qualitative component of the study.

Data analysis was essentially computer-assisted especially for the quantitative component. Qualitative data were reduced, grouped into meaning units and thematically analysed (Bogdan \& Biklen, 1982).

In the quantitative study reliability and validity of data were promoted by using the same carefully considered research instruments with all professional groups. The systematic pretesting of the questionnaire was central to planning the quantitative data collection (American Statistical Association, 1998). A total of five respondents (who did form part of the total sample) were randomly selected from UKZN Howard College to pre-test the questionnaire. Validity was also enhanced through a thorough literature search so that the instruments correctly and optimally researched the topic (Royce, 2004:128).

In the qualitative component of the study, the students conducted the fieldwork in hospital settings which formed their fieldwork practice setting for a year. The advantage of this was that they had prolonged as well as established relationships in these settings, which contributed to the trustworthiness of the data (Babbie \& Mouton, 2001). Trustworthiness was further enhanced by peer debriefing (the data collectors and principal researchers met for supervision weekly). All of these strategies helped the researchers to ensure high reliability of the data collected for the study.

\section{Ethical considerations}

The ethical guidelines outlined by Royse (2004:51-59) were respected as follows: no harm to respondents; anonymity; respondents not having unrealistic expectations of the study by being appraised of intent before agreeing to participate; receiving informed consent from participants and gatekeepers; and being informed of publishing research findings with due regard to confidentiality and anonymity. Furthermore, ethical clearance was obtained from the Research Committee of the University of KwaZulu-Natal to conduct the study.

\section{Limitations of the study}

- Respondents were often unwilling to set time aside to complete the questionnaires and interviews, and needed several reminders to return the questionnaires. Those who were interviewed were often rushed and thus rushed the research assistants. This may have compromised the nature and/or quality of responses that were finally received.

- Some professionals were critical of the questions, wanting to "correct" and "offer suggestions" on how the questions could be asked differently. This had to be delicately negotiated as again the assumed superiority of the other professional was being imposed. This may have negatively influenced the quality of responses provided by participants.

- Where a pre-existing relationship between researcher and respondents existed, it was possible that answers were not always honest for fear of hurting the student social worker.

\section{RESULTS AND DISCUSSION}

Results are presented and discussed in accordance with the research objectives listed above. Both the quantitative and qualitative study results are separately presented, but comparisons are made where appropriate.

Sample details are first outlined for the quantitative and then the qualitative sectors of the study. 


\section{TABLE 1}

PROFESSION AND GENDER OF RESPONDENTS IN THE QUANTITATIVE COMPONENT OF THE STUDY

\begin{tabular}{|l|c|c|c|c|c|}
\hline Profession & Female & Male & N R & N & Total \\
\hline Police & 5 & 9 & & 1 & 15 \\
\hline Nurses & 13 & 2 & & & 15 \\
\hline Educators & 4 & 8 & & & 12 \\
\hline Doctors & 7 & 5 & & & 12 \\
\hline Total & 29 & 24 & & 1 & 54 \\
\hline
\end{tabular}

The gender distribution above is consistent with the trend in each profession, e.g. many more female nurses than males being attracted to nursing, as compared to the gender variations in the other professions.

Similarly, the gender distribution in the qualitative sample was six female nurses, five male and one female doctor, six female VCT counsellors, and three male and one female psychologist.

\section{NEED FOR AND KNOWLEDGE OF SOCIAL WORK}

In the quantitative component of the study professionals were asked their opinions on the need for social work and were given a list of functions that they could rate as important.

TABLE 2

IMPORTANCE OF SOCIAL WORK FUNCTIONS

\begin{tabular}{|c|c|c|c|c|c|c|c|c|c|}
\hline 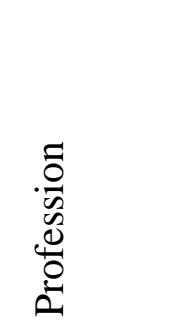 & 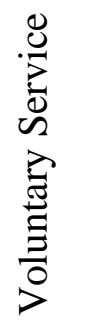 & 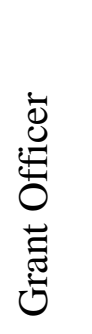 & $\stackrel{\vec{D}}{\vec{D}}_{\overrightarrow{0}}$ & 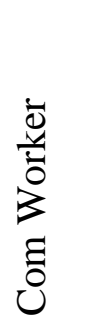 & 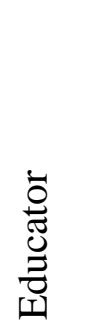 & $\frac{\Xi}{g}$ & 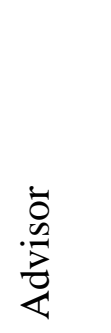 & 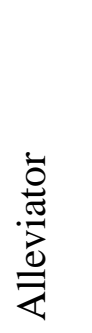 & $\begin{array}{l}\overrightarrow{0} \\
\stackrel{\vec{D}}{0} \\
\omega \\
\overline{0} \\
\frac{0}{0} \\
0 \\
0\end{array}$ \\
\hline & $\%$ & $\%$ & $\%$ & $\%$ & $\%$ & $\%$ & $\%$ & $\%$ & $\%$ \\
\hline Doctor & 75 & 67 & 100 & 100 & 83 & 83 & 100 & 75 & 100 \\
\hline Educator & 83 & 75 & 83 & 100 & 68 & 83 & 83 & 76 & 67 \\
\hline Nurse & 60 & 80 & 93 & 93 & 86 & 73 & 93 & 73 & 73 \\
\hline Police & 87 & 67 & 73 & 80 & 60 & 40 & 73 & 60 & 87 \\
\hline
\end{tabular}

Professionals had different levels of understanding about the functions of social workers as evident from their responses. This is explicated further below.

\section{Voluntary service provider}

The majority of respondents (specifically doctors, police and educators) indicated that social workers are mainly voluntary service providers. This clearly shows that social workers are viewed as volunteers, which may not be demanding nor require professionalism, an erroneous impression, given the professional status and the intensive training and time it takes to complete a social work degree. This response may originate from the history of social work in 
the 1800s and its charity-work roots, where volunteers visited the poor (Mullaly, 1997; Potgieter, 1998) on a voluntary basis to offer material and social support. These interventions were merely band-aid solutions and did little to challenge the institutional structures in society that entrenched exploitation of the poor.

\section{Grant officer and poverty alleviator}

This was the role attributed to the social worker by mainly educators and nurses. Yet this function of social work is only one of many, as suggested by Bernstein and Gray (1997). Given the scale of poverty in the country (Kasiram, 2009), this onerous responsibility is interwoven with state assistance and understandably perceived as an important function. The fact that there was not $100 \%$ agreement of the import of these functions could also suggest that the actual performance of this function is ineffectual. It is also important to bear in mind that antioppressive theory perceives therapeutic, social policy and emancipatory approaches to practice as not mutually exclusive from each other, but intricately linked (Dominelli, 2002a).

\section{Driver}

Social workers undertake home visits which translates into a driver's licence being a prerequisite for employment. This employment requirement appears to have mistakenly led to confusion about the job of the social worker being that of a driver as well! Dominelli (2002a) notes that the ethical and justice position of anti-oppressive practice obliges social work practitioners not just to challenge professionals with such misconceptions, but to endeavour to change the structures that entrench them. Such negative perceptions of social workers' roles and functions need to be addressed particularly in a multidisciplinary setting so that team expectations are corrected in such a way that social workers may then concentrate on professional functions attributed to them.

\section{Community worker}

All professionals rightfully regarded community work as a significant function and responsibility of the social worker. However, some police did not consider community work an important social work function, presumably as they themselves perform this function and did not view social workers as worthy team members. It was noteworthy that even doctors and educators knew that social work involved community work. The questionnaire did not ask if this function was indeed performed satisfactorily, which would have produced interesting results, particularly from police who seemed to consider this their area of work.

\section{Educator}

Educators and the police viewed education as a core social work function less than doctors and nurses did. It seems that where a professional is identified with a certain function, such as the doctor with educating and the police with community work, that they regard it as their exclusive domain and not an important function of the social worker. Evidence of territoriality is apparent in this and social justice-oriented practice requires that social workers engage with such key professionals in dialogue, education and consciousness-raising regarding the functions of social workers and the development of social systems based on fairness and justice (Baines, 2007). However, it was interesting that educators themselves believed that social workers performed an educative function. This may be attributed to educators seeing the need for support on education in aspects such as life skills and subjects that they simply do not have time to cover in the classroom. 


\section{Administrator}

Social workers are required to keep statistical records of various aspects of their work, or if in management positions, are required to perform various administrative functions. All professionals in the quantitative component saw this as a key function. Only the police did not view administration as a significant role and function. Perhaps the meaning of administration was unclear to them, and this being a questionnaire, it did not allow for clarification.

\section{Advisor and problem solver}

Advising and problem solving are key roles of the social worker. All professionals regarded these as quite important, except for police in respect of the "advisor role" and educators in respect of the "problem solver" role. These responses may be attributed to a possible lack of teamwork with social workers, or their simply not being convinced that social workers can perform these functions well.

Another question that addressed the perceived need for social workers in the quantitative study was related to whether social workers may be replaced by non-social workers. The table below tabulates these findings.

TABLE 3

REPLACING SOCIAL WORKERS

\begin{tabular}{|l|c|}
\hline Profession & Affirmative for replacing social workers \\
\hline Doctor & $58 \%$ \\
\hline Nurse & $73 \%$ \\
\hline Police & $53 \%$ \\
\hline Educator & $58 \%$ \\
\hline
\end{tabular}

It was disturbing that more than half of each respondent category considered social workers to be easily replaced by non-social workers! Perhaps the results pertaining to qualifications required by social workers may illuminate this finding. These are presented below.

TABLE 4

QUALIFICATION NECESSARY FOR SOCIAL WORK PRACTICE

\begin{tabular}{|l|c|c|c|c|}
\hline Profession & None & Diploma & Degree & Postgraduate \\
\hline Doctor & $9 \%$ & $25 \%$ & $66 \%$ & $0 \%$ \\
\hline Police & $0 \%$ & $47 \%$ & $47 \%$ & $6 \%$ \\
\hline Nurse & $0 \%$ & $60 \%$ & $26 \%$ & $14 \%$ \\
\hline Educator & $0 \%$ & $8 \%$ & $67 \%$ & $25 \%$ \\
\hline
\end{tabular}

Table 4 illustrates that some doctors did not think social workers required any training at all, and almost half the police and $60 \%$ of nurses considered only a diploma necessary for practice. Such misconceptions regarding the education, training and qualifications of social workers among these key human service professionals provide support for the marginalisation and devaluing of social work. The views expressed here illustrate the power imbalances that exist between other key professionals and social workers in organisations. Rather than simply ignoring such misconceptions, Baines (2007:19) suggests that anti-oppressive social workers need to challenge such attitudes and examine how management practices entrench them. 


\section{CHALLENGES IN WORKING WITH SOCIAL WORKERS}

The qualitative component provided further evidence for understanding the devaluing of the profession and illuminated the quantitative results.

When doctors, nurses and psychologists were asked what challenges were encountered in teaming with social workers, they referred to concerns about inefficient services, poor educational qualifications (a misnomer) and that perhaps social workers were ignorant of the role and function of other professionals. Some psychologists spoke about role conflict and the negative attitude that social workers have about their profession. One psychologist stated:

Psychologists will more often get deeper or broader into the patient's life story or thoughts whilst social workers will have a negative attitude towards our profession.

One nurse commented:

I tried to refer a patient by calling the social work department and no one answered and therefore the patient had to be seen the following day.

A doctor revealed:

Sometimes limited feedback is given to clinicians regarding the status of the problem of the patient and often a limitation in recognizing the urgency with certain issues.

The negative sentiments shared by the doctors, psychologists and nurses in the two hospital settings triangulated the negative perceptions that the police personnel, nurses, doctors and educators who participated in the quantitative phase of the study had. Baines (2007:23) argues that such micro-level social relations not only shape but perpetuate notions of polarised positions such as superiority and inferiority, and thus influence the quality of our work experiences. The doctors and nurses who formed part of the sample of the qualitative study also referred to lack of collaboration and time constraints as major obstacles to positive networking. One doctor stated:

We all tend to care for our patients in our own departments and do not collaborate enough. It is a challenge to schedule training and staff consults due to limited time and resources.

It was clear that the professionals working in multidisciplinary settings were keen to improve collaboration and networking between themselves and social workers. However, macrostructures such as financial, time and workplace policies hindered such engagements. Baines (2007:29) makes the point that it is a combination of these macro- and micro-level social relations that undermine and reinforce oppression of one group over another.

\section{POSITIVE SENTIMENTS ABOUT WORKING WITH SOCIAL WORKERS}

Despite some of the negative sentiments shared, 21 of the participants in the qualitative sample revealed that they valued social workers and had positive relationships with them. Some of the sentiments shared by the respondents included:

The relationship is very good in all spheres, be it in OPD or the wards, we use a multidisciplinary team approach [a medical doctor].

Social workers, psychologists, the psychiatrist and nurses, network closely with the placement of psychiatric patients [a medical doctor].

There is a good collaborate relationship that exists because we co-relate and refer patients with social issues [a nurse]. 
The relationship is very good because social workers are able to touch on social issues and together we assist the patient holistically [VCT counsellor].

Ten $(45 \%)$ of the participants within the multidisciplinary hospital setting asserted that social work intervention had improved patient outcomes and that they gained vast experience from working with social workers. Some indicated that they had learnt how to problem solve and manage patients efficiently and more appropriately in respect of the process of admissions and discharge. Many of the participants acknowledged that more comprehensive care was available to patients and their families as a result of the social workers' role. One VCT counsellor explained:

The HIV/AIDS team is incomplete without the social workers.

A nurse stated:

Before social work services were active, this hospital experienced an overload of work.

Patients now get better support network around them and they get the help they need for all their problems.

One medical doctor noted:

I do recognise social work as a very important profession, but I don't think that South

Africans in general see the importance of this service offered to them.

Jones (2001:46) argues further that since its inception social work has been "marked by a long process of struggle for legitimacy and acceptance". However, it is important to acknowledge human rights social work leaders such as Mary Richmond and Eileen Younghusband, who advocated for the legitimacy of the profession and confidently fought that social work, had the knowledge and skills to ensure fairness and equity for the downtrodden and marginalised in society. Dominelli (2002b:3) adds that discussions of the role and purpose of social work have mainly entailed debates between individual interventionists and social activists. In contemporary South Africa these issues continue to be hotly contested by social workers in the transition to developmental social welfare. Gray (1996:12) states further that policy makers have even chosen to blame social workers for "not doing their jobs properly" and have absurdly asked: "Is there a place for them in development?" (Gray, 1996:12). This, together with poor salaries, subsidy cut-backs, poor working conditions and a sense of feeling marginalised and alienated in relation to other social service professionals (Kasiram, 2009), has contributed to the current low status of the profession. However, the positive establishment of the national professional association in September 2007 (NASW SA) is a positive step towards improving the status and image of the profession. Dominelli (2004) and Baines (2007) aptly note that merely acknowledging oppressive reality is insufficient, but establishing mechanisms to engage with existing structures in order to mobilise for change is the core of social justice-oriented social work.

\section{IMPROVING PROFESSIONAL STANDING}

In the quantitative part of the study, an open-ended question was asked pertaining to how social work can improve its professional standing. Most doctors and nurses suggested that social workers need better salaries to spur them to improve service delivery and thereby their professional standing. All professionals suggested the need for more social workers and recruitment drives to address the shortfall of social workers in the country, as discussed by Kasiram (2009:649). This will have a ripple effect in positively influencing services and the professional image of the profession. 
Other suggestions were for continuous training endeavours to improve service delivery and professional standing in the community. A few doctors (17\%) suggested that social workers structure their services legally to prevent lay people from offering social work and tarnishing the image of the profession by offering poor-quality services.

A significant recommendation was that social workers "advertise" services to the public for an improved understanding of what social work is about, thereby dispelling misconceptions and a poor professional image. In the qualitative study this was also recommended by respondents. Hospital professionals discussed the need for social workers to advertise their role and function by organising awareness campaigns and orientation and open-day programmes for all staff to improve the image and clarify misconceptions. One psychologist remarked that:

More social workers need to prepare research papers and presentations that could be exposed to other professionals.

A further suggestion made was that:

Hospital policies and programmes need to integrate different professions working alongside each other.

\section{CONCLUSIONS AND RECOMMENDATIONS}

After 1994 social work as a core human service profession continues to struggle for legitimacy and acceptance from other key human service professionals. Social workers are leaving the profession in vast numbers (Naidoo \& Kasiram, 2003) and those who are left behind experience low morale and disillusionment. Even though the findings of this study revealed a mixed response, it is evident that a mainly distorted and inaccurate perception of social work amongst other key human service professionals prevails. Even with functions that were considered important, such as community work and problem solving, these were considered as not being performed optimally. However, a more positive image prevailed among some hospital staff where social workers worked as part of a multi-professional team and enjoyed close working relationships, and they were then able to serve their clientele holistically.

A disconcerting conclusion from the study was that of role confusion, role overlap and role conflict across almost all professionals/respondents in both sectors of the study.

Recommendations for improving the professional standing of social work were made by respondents; these are summarised below together with recommendations from the authors.

- Social workers need to take responsibility for correcting their own image in their respective work settings through honest appraisal and then taking corrective action through e.g. workshops, in-service training, staff meetings, etc.

- At a broad level the South African Council for Social Work and Social Service Professionals and social work agencies need to set right stereotypes at a preventive level through awareness campaigns and mass advertisements about entrance requirements, qualifications, role and function, and access to social workers.

- The education and training of the social worker needs to cover assertive skills and interprofessional teaming to ensure effective teaming and enable the social worker to assert her professionalism with confidence.

Finally, further research should be conducted on a larger scale using different settings and a larger sample for increased generalisability. Traditionally social work prides itself on respecting and dignifying other people, valuing difference and meeting the end goals of social justice. These are aspects of social work that we must abide by wherever social work is 
practised. In sum we echo the sentiments of the academic, Vivenne Cree (2002:27), who states that social work can "either fight to hold onto its nascent professional status, in the face of the encroachment of other professional groupings or it can take a step back and try to recover its purpose and its expertise".

\section{REFERENCES}

ALLAN, J. 2003. Theorising critical social work. In: ALLAN, J., PEASE, B. \& BRISKMAN, L. (eds) Critical social work: an introduction to theories and practices. Sydney: Allen and Unwin.

AMERICAN STATISTICAL ASSOCIATION. 1998. Judging the quality of a survey. Survey Research Methods, Alexandria, USA. UNAUTHORED.

BABBIE, E.R. \& MOUTON, J. 2001. The practice in social research. New York: Oxford University Press.

BAINES, D. 2007. Anti-oppressive social work practice: fighting for space, fighting for change, In: BAINES, D. (ed) Doing anti-oppressive practice: building transformative politicized social work. Halifax: Fernwood Publishing.

BERNSTEIN, A. \& GRAY, M. 1997. Social work: a beginner's text. South Africa: Juta and Co.

BOGDAN, R.C. \& BIKLEN, S.K. 1982. Qualitative research for education: an introduction to theory and methods. Boston: Allyn \& Bacon, Inc..

CHILD WELFARE SOUTH AFRICA. 2004. Executive summary: working conditions of social workers employed by Child Welfare. Johannesburg: Child Welfare South Africa.

CREE, V.E. 2002. The changing nature of social work. In: ADAMS, R., DOMINELLI, L. \& PAYNE, M. (eds) Social work: themes, issues and critical debates $\left(2^{\text {nd }}\right.$ ed). New York: Palgrave MacMillan in association with The Open University.

DITTRICH, K.M. 1994. Integrating social welfare policy and social work practice. Pacific Grove, Calif.: Brooks/Cole.

DOMINELLI, L. 2002a. Anti-oppressive practice in context. In: ADAMS, R., DOMINELLI, L. \& PAYNE, M. (eds) Social work: themes, issues and critical debates $\left(2^{\text {nd }}\right.$ ed). New York: Palgrave MacMillan in association with The Open University.

DOMINELLI, L. 2002b. Anti-oppressive social work theory and practice. New York: Palgrave MacMillan Publication.

DOMINELLI, L. 2004. Social work: theory and practice for a changing profession. Cambridge: Polity Press.

GRAY, M. 1996. The role of social workers in developmental social welfare: is there a place for them? Social Work Practice, (2):8-13.

HOLSCHER, D., KASIRAM, M. \& SATHIPARSAD, R. 2009. "Deserving" children, "undeserving" mothers? Multiple perspectives on the child support grant. Social Work/Maatskaplike Werk, 45(1):11-27.

IFE, J. 2001. Human rights and social work: towards rights-based. Cambridge: Cambridge University Press. 
JONES, C. 2001. Voices from the front line: state social workers and New labour. British Journal of Social Work, 31(4):547-562.

KASIRAM, M. 2009. The emigration of South African social workers: using social work education to address gaps in provision. Social Work Education: The International Journal, 1470-1227, 28(6):646-654.

MULLALY, B. 1997. Structural social work: ideology, theory and practices ( $2^{\text {nd }}$ ed). Toronto: Oxford University Press.

NAIDOO, S. \& KASIRAM, M. 2003. Social work in South Africa: Quo Vadis? Social Work/Maatskaplike Werk, 39(4):372-380.

POTGIETER, M.C. 1998. Social work process: development to empower people. South Africa: Prentice Hall.

RANIGA, T. 2006. The implementation of the national life-skills and HIV/AIDS programme and policy in the eThekwini region. Durban: University of KwaZulu-Natal. (Unpublished PhD Thesis)

ROYCE, D. 2004. Research methods in social work $\left(4^{\text {th }}\right.$ ed). USA: Thomson Brooks/Cole.

SHERA, W. 2003. Emerging perspectives on anti-oppressive practice. Toronto: Canadian Scholars Press, Inc.

SEWPAUL, V. 2005. Structural social justice approach to family policy: critique of the Draft South African Family Policy. Social Work/Maatskaplike Werk, 41(4):310-322.

SEWPAUL, V. 2006. The global-local dialect: challenges for African scholarship and social work in a post-colonial world. British Journal of Social Work, 36:419-434.

TERRE BLANCHE, M. \& DURRHEIM, K. (eds) 1999. Research in practice: applied methods for the social sciences. Cape Town: University of Cape Town Press.

Dr Tanusha Raniga, Prof Madhu Kasiram, School of Social Work and Community Development, University of KwaZulu-Natal, Durban, South Africa. 